\title{
The exploitation of wild plants in Neolithic North Africa. Use-wear and residue analysis of non-knapped stone tools from the Haua Fteah cave, Cyrenaica, Libya.
}

\section{Giulio Lucarini ${ }^{1}$, Anita Radini ${ }^{2}$, Huw Barton ${ }^{3}$, Graeme Barker ${ }^{1}$}

\section{Introduction}

The origin of food production is one of the key themes in North African pre-/proto-history. In recent years the orthodox model, that domesticated plants and animals were introduced by maritime Neolithic colonists from the Near East, has been increasingly challenged, and a component of autonomous development independent of the Near East acknowledged (Barker, 2009; Bellwood, 2005; Krzyżaniak and Kobusiewicz, 1984; Smith, 2005). However, there remains considerable uncertainty about the nature and extent of, and interplay between, internal and external dynamics in the beginnings of food production across North Africa.

It is commonly accepted that domestic caprines from the Near East were introduced into North Africa at the end of the $9^{\text {th }}$ millennium cal BP (Gautier 2014; Linseele et al., 2010; Vermeersch et al. 2015). The new species came into contact with existing subsistence systems mainly based on an intensive exploitation of different wild resouces, mainly local wild grasses, e.g. sorghum and millets (Barakat and Fahmy, 1999; Barker et al., 2010; Fahmy, 2001, 2014; Lucarini, 2014; Mercuri, 2001; Thanheiser, 2011; Wasylikowa, 2001; Wasylikowa et al., 1995).

Concerning a possible authocthonous cattle domestication, the interpretation of the Bir Kiseiba (southern Egyptian Western Desert) bovid remains dated to $11^{\text {th }}$ millennium BP, as locally domesticated cattle, is still controversial (Gautier 1980, 1984, 2001; Jórdeczka et al. 2013; contra Smith 2005); so far, the earliest evidence of North African cattle, which are unanimously accepted as domestic are dated to the end of the $9^{\text {th }}$ millennium BP (di Lernia 2013; Barich 2014).

As for the presence of domestic crops in the Sahara and along the North African littoral, the only two areas that have yielded evidence of domestic crops exploitation during the Mid Holocene are the Fayum Oasis, in Egypt and the northern coast of Morocco (Morales et al.,

\footnotetext{
${ }^{1}$ McDonald Institute for Archaeological Research, University of Cambridge.

${ }^{2}$ Department of Archaeology, University of York.

${ }^{3}$ School of Archaeology and Ancient History, University of Leicester.
} 
2013; Wendrich et al., 2010). Both these regions yielded charred macro-remains of wheat and barley dated ca. 7000 to $6700 \mathrm{cal}$ BP. Being located on the opposite ends of the North African coast, these areas have been exposed to different influences, Levantine for the Nile Delta and Fayum, and Iberian for the Moroccan coast. More recently, domestic wheat/barley phytoliths and starches were also retrieved from dental calculus of individuals buried in two Sudanese cemeteries dated at least 7000 years ago (Madella et al., 2014).

Located in the middle of the North African littoral, the Mid Holocene contexts of Cyrenaica (northeastern Libya) yielded remains of domestic caprines starting from the first half of the $8^{\text {th }}$ millennium cal BP, but no macro-remains of domestic crops have been identified so far (Barker et al., 2010; de Faucamberge, 2015); yet what happened in this region is critical in terms of understanding how domesticates spread across the southern Mediterranean littoral and how their use integrated with the exploitation of wild plants.

This paper investigates potentials and limitations of selected ground stone tools from the Neolithic layers of the Haua Fteah Cave, to provide new information on the function of tools, by applying an integrated approach of use-wear and residue analysis, focusing in particular on starch granules. In doing so we also test survival of micro-debris in the residues and their potential pathways of inclusions.

The results of this paper confirmed the lack of proper farming activities in Cyrenaica during the Mid Holocene, and confirm that the exploitation of wild resources, mainly shellfish (Hill et al. 2015; Hunt et al. 2011), wild game and plants, was not replaced by the introduction of domestic small livestock in the region at the beginning of the $8^{\text {th }}$ cal BP. On the contrary, the picture emerging from the palaeoeconomic data highlights the adoption of a more complex - and successfull - strategy, in which domestic caprines from the Levant integrated a local Epipalaeolithic-tradition subsistence based on an intensive exploitation of wild resources.

\section{Regional setting and project background}

The Haua Fteah Cave has yielded important evidence of human occupation of the North African littoral between the end of Pleistocene and the beginning of Holocene. The Haua Fteah is a huge limestone karstic concavity located c. $10 \mathrm{~km}$ east of the ancient city of Apollonia, c. $20 \mathrm{~km}$ north of Cyrene and less than a kilometer from the Mediterranean shore (Fig. 1). The cave opens onto the lowest terrace of the Jebel Akhdar. It is north oriented, c. $20 \mathrm{~m}$ high and c. $80 \mathrm{~m}$ wide. 
After a preliminary season carried out in 1948, the initial fieldwork here started under C.B.M. McBurney in 1950, and continued in 1951 and 1955. The different trenches excavated during these seasons came to be consolidated into a single large stepped excavation, $14 \mathrm{~m}$ deep, consisting of an 'Upper Trench' (10 x 10 m, 2 m deep), a 'Middle Trench' ( 8 x 7 m, 6 m deep) and a 'Deep Sounding' (2.5 x 1.5 m, 6 m deep) (Barker et al., 2009: 2-3) (Fig. 2). McBurney brought to light a stratigraphical sequence, made up of 35 different layers, spanning along at least the last 80,000 years, which is now considered as the one of the most important sequence of human occupation in North Africa. The initial results were published in a comprehensive monograph (McBurney, 1967), which still represents a key point of reference for the archaeological study of the whole region.

Fifty two years later, in 2007, a new interdisciplinary cycle of research (The Cyrenaica Prehistory Project [CPP]), led by Graeme Barker, was begun to re-investigate the Haua Fteah and other caves of the region - most notably, Hagfet ed-Dabba and Hagfet al-Gama) - but also to survey the whole Jebel Akhdar and pre-desert areas (Barker et al. 2007; 2008; 2009; 2010; 2012). The CPP has aimed to investigate the relationships between cultural and environmental change over the past c. 200,000 years in northeast Libya, addressing two major questions about human settlement: the colonization of North Africa by Homo sapiens and the beginning of farming in the North African littoral (Barker et al. 2009: 1-2).

Although the Pleistocene sequence of the cave and the issues connected with the dispersal of Homo sapiens in North Africa have been intensively investigated, due to the political situation of the last years and the difficulty in carrying out fieldwork, the Holocene sequence remained essentially untouched. After the Upper Trench backfill was completely removed, during the 2007 field campaign, the exposed trench walls were cleaned. Only a sample column and a small trench (named Trench $U$ ) have been opened in this section of the sequence but these deposits did not yield any new grinding implements. Given this lack of new data, we had to rely mainly on the archive materials coming from Layers VIII and VI of the cave, excavated by McBurney and kept at the Museum of Archaeology and Anthropology of the University of Cambridge.

Eleven dates are available for the Neolithic layers (VIII and VI) of the Upper Trench. Four were obtained by McBurney and seven come from the sample column excavated by the

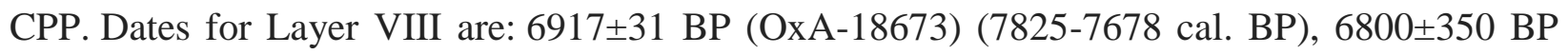

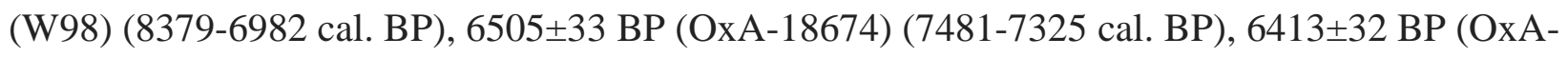


19028) (7419-7275 cal. BP), 6370 \pm 103 BP (NPL-42) (7477-7013 cal. BP), and 6115 \pm 31 BP

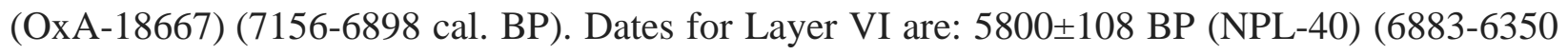
cal. BP), 5759 \pm 28 BP (OxA-18675) (6641-6485 cal. BP), 5521 32 BP (OxA-18794) (6398-6281

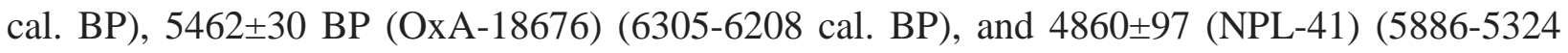
cal. BP) (Barker et al., 2009: 36; Douka et al. 2014: 46) (Fig. 3).

McBurney's excavation was carried out by removing artificial spits, which sometimes crossed different stratigraphic layers. Since the collected materials were grouped and labelled according to these spits, it is not always possible to indicate precisely which stratigraphic layer a certain tool derives from. This is why in chapter 4 some tools are labelled with reference to multiple layers. This also renders it impossible to specify the exact age of some tools within the wider range of Neolithic dates presented above.

\section{The ground stones assemblage and the tools selection}

The study sample consisted of a total of 79 informal stone implements derived from the Neolithic levels of the Upper Trench as well as another 38 artefacts from the basal layers of Upper Trench broadly dated between the Neolithic and Libyco-Capsian. These tools consisted of unmodified pebbles and other stones with visible evidence of use including, grinding stones, anvils for bipolar knapping technique (defined as "counter-sunk pebbles" by McBurney, 1967), hammerstones, polishers and abraders, palettes, ochre pestles, painted pebbles, mainly of very small dimensions (1-4 cm in diameter).

The artefacts do not usually show any manufacturing, since limestone pebbles, available in a great number in the area between the cave and the littoral, were usually exploited. Only two ground handstones were found. As for possible grinding equipment it has to be stressed that only upper grinders / handstones have been found in the cave. The excavation of the Upper Trench did not yield any lower quern. We can assume that plant-processing activities could be carried out outside the cave and/or areas of outcropping bedrock could be used as dormant elements. Considering that the cave is quite large, it also cannot be excluded that the lower stones might simply lie in unexcavated deposit.

Of the 79 implements initially identified we were able to identify a total of six handstones (upper grinding stones) with morphological features consistent with their probably use as 
grinding and abrading tools (tools A1, A4, A5, A6, A7 and A8). These implements were then subjected to further detailed functional analysis. As a control sample, two pebble tools; an anvil and an unworked pebble (tools A2 and A3) were also assessed to identify traces of use and/or the presence of contaminating plant/animal residues.

\section{Low magnification usewear analysis}

The identification and characterisation of the usewear was carried out with low magnification observation using an incident-light stereomicroscope Leica M250C at magnifications between $8 \mathrm{x}$ and 160x. Recorded features such as levelled (flattened) areas, fractures, edge rounding and polish follow the protocol developed by Adams et al. (2009).

\subsection{Artefact 1 - HFT 1955/7 - HFT 399.00-55 (Layer VI-VIII)}

Artefact 1 is a ground turtleshell-type handstone manufactured in sandstone and measuring $141 \times 99 \times 60 \mathrm{~mm}$ that is semi-ovoid in shape (Fig. 4). Two ground surfaces were identified; a lower flat grinding surface and an upper convex surface. The lower grinding surface is characterized by a sinuous regular topography around its perimeter, and by an uneven irregular topography mainly concentrated on its central area. The irregular features in the central area of the lower surface appear to result from re-pecking activity.

The sinuous perimeter shows levelled areas and slightly reflective polish mainly concentrated on the topographic high points (Fig. 4, b). Deep pits, which are places vacated by grains extracted during the use (Adams et al. 2009: 53), and fractures are present as well. Due to the raw material's coarseness and the presence of coarse grains attached together almost without matrix, it is not possible to determine the orientation of the extracted grains. The perimeter also shows white crust-like areas that can be interpreted as the result of levelling and fracturing action of the raw material grains (Fig. 4, d). A series of short, shallow and parallel striations were also identified (Fig. 4, a).

The uneven central area of the surface has an irregular topography with alternating deep/step depressions caused by re-pecking. The highest topographic points do not show any sign of edge rounding, polish or levelled areas. The surface shows small fractures on the grain surface. 
Fractures are not so well developed and deep and this could be due to re-pecking activity that, cause of the coarse nature of the raw material, mainly caused grain extraction rather than fractures.

Small dark brown or orange crusts are present on the whole surface; most of which are directly associated with polished mineral grains and levelled areas (Fig. 4, c). Seven extraction points were selected in correspondence with the visible residues.

The upper convex surface has pronounced edge rounding along its perimeter with a reflective, greasy polish distributed across the central area and edges (Fig. 4, e). As reported by other scholars (Dubreil 2002: 189; Hamon 2008: 1515-1516), macroscopically visible sheen and distinctive smoothing of the rock grain edges usually characterize tools used in hide softening and defleshing of hide. Considering distribution and extension of the area, which is affected by this kind of wear and the pronounced convexity of this surface, we interpret this not as the result of contact with hide, but as possible prehension wear caused by a prolonged contact with the hand's palm. There were no linear traces to indicate the preferred mode of use and there were no levelled areas. Small white crust-like areas are also present on the convex surface that may have resulted from accidental contact with stone or as result of pitting activities. Two extraction points were selected on this surface.

\subsection{Artefact 2 - HFT 1955/7 - HFT 399.00-55 (Layer VI-VIII)}

Artefact 2 is a disk shaped nummulitic limestone pebble, measuring 89 x 86 x 39 mm (Fig. 5). It has two flat surfaces, characterized by levelled (Fig. 5, b) and pecked areas mainly concentrated in the central area of the disk, thus forming two opposed small, shallow depressions (Fig. 5, a). This suggests its use as an anvil for bipolar percussion. Levelled areas have some patches of pecking and striations. Along the apex of the tool edge, half of the tool's circumference is battered indicating use of this area as a hammerstone (Fig. 5, c). Two extraction points were selected associated with a brownish residue and an additional extraction point was selected in relation to a yellowish substance.

\subsection{Artefact 3 - HFT 1955/7 - HFT 399.00-55 (Layer VI-VIII)}


Artefact 3 is a small egg shaped limestone pebble measuring 35 × 29 x 26 mm (Fig. 6). Its surface shows a flat regular topography and is characterized by levelled areas mainly concentrated on the topographic high points. Deep fractures are mainly concentrated on the two ends of the tool, thus suggesting its use as small hammerstone or retoucher (Fig. 6, b). A series of long and short deep striations, parallel or random disposed, are also visible all over the surface (Fig. 6, a). Considering this, it is possible that this tool was also used as an abrader, to grind the cortex surface of the pressure-flaked tools, such as a bifacial knife manufactured on side-blow flake, which shows linear striations on its cortical surface (McBurney 1967: Fig. IX.10.4). One extraction point was selected on its surface.

\subsection{Artefact 4 - HFT 1955/3 (1) - HFT 192.09 (Layer VI)}

Artefact 4 is a fragmentary limestone disk shaped pebble measuring 110 x 97 x 26 mm (Fig. 7). It shows two, one slightly convex and one slightly concave, grinding surfaces. Topography is flat irregular for both the surfaces.

The slightly convex surface is characterized by edge roundings and a moderately reflective polish mainly spread on the highest topographic points. Pits and superficial fractures are also present. The central area of the surface shows a sort of shallow circular depression, c. $8 \mathrm{~mm}$ in diameter, evidence of a possible secondary use of the tool as an anvil (Fig. 7, a). Around the circular depression there are some white areas, probably result of quartz grains breakings. No evident linear traces are visible. Three extraction points were selected on this surface in relation to brown patches attached to the tool, and one on the fractured surface as a control point.

The slightly concave surface is also characterized by edge roundings, with moderately reflective polish mainly spread on the highest topographic points (Figs. 7, b-c). Pits and superficial fractures are also present (Fig. 7, d). Similarly to the other surface, also this one shows a sort of small shallow circular depression, c. $13 \mathrm{~mm}$ diameter, that points to a secondary use of the tool as an anvil. One extraction point was selected on this surface in relation to a large brown patch attached to the tool.

\subsection{Artefact 5 - HFT 1955/5 - HFT 193.14.2005 (Layer VI-VII-IX-X)}


Artefact 5 is a fragmentary nummulitic limestone disk shaped pebble, measuring $67 \times 80 \times$ $28 \mathrm{~mm}$ (Fig. 8). It shows two opposed surfaces, which are irregularly flat in topography (Fig. 8, c). Both the surfaces show levelled and fractured areas (Figs. 8, a, d). The levellings are limited to the high topographic points and show a flat morphology and a rough texture. Fractures are superficial with no specific orientation. One of the two surfaces shows parallel, long, shallow striations. The two surfaces are characterized by the presence of brown residues attached to the tool, some of them showing a shining surface (Fig. 8, b). Three extraction points were selected on each surface in relation to these brown residues.

\subsection{Artefact 6 - HFT 1955/9 - HFT 160.02.2005 (Layer VIII)}

Artefact 6 is a turtleshell shaped nummulitic limestone pebble used as a handstone. It measures 124 x 94 x 46 mm (Fig. 9). It shows one convex and one slightly concave surface. The slightly concave surface shows a flat regular topography. It is completely levelled and highly polished. The cavities visible on the surfaces are the negative impressions left by fossil shells. Levelling affects high and low topographic points, creating a flat morphology and a smooth texture (Fig. 9, a). A highly reflective polish is spread all over the surface, affecting both high points and interstices (Fig. 9, b). Siliceous fibrous plant residues were detected inside one of the small cavities on the tool's surface (Fig. 9, d). Due to the uniqueness of this find and the possibility to retrieve information about the exploited plant species from the other residues extracted from the surface, we decided to leave these plant fibers in situ. Three extraction points were selected on this surface in relation to brown patches attached to the tool. In the central part of the surface, these brown patches are highly reflective and characterized by parallel linear striations that are not present on the tool's surface (Fig. 9, c). In each patch, these striations are always parallel and follow the same orientation, but from patch to patch their orientation is not the same. It is possible that the striations could be due to a prolonged grinding activity that affected residues that were already attached to the surface.

The convex surface of the tool has also been used. It shows a sinuous irregular topography characterized by levellings, highly polished areas and rounded edges. Levellings only affect high topographic points and show a flat morphology and a smooth texture. A high reflective polish also affects the high topographic points (Fig. 9, f). The central area of the surface also shows 
fractured grains, due to possible re-pecking activity (Fig. 9, e). Highly weathered and fractured areas are present along the edge of the surface and on the tool's profile. These features may point to a secondary use of the tool as a hammerstone. The surface shows only a single deep oblique short, V-shaped striation. Five extraction points were selected on this surface in relation to brown patches associated with very levelled areas.

\subsection{Artefact 7 - HFT 1955/3 - HFT 192.20(LAYER VI)}

Artefact 7 is a fragmentary nummulitic limestone pebble used as a handstone and measuring 57 x 68 x $32 \mathrm{~mm}$ (Fig. 10). The preserved surface is slightly concave and shows an irregularly sinuous topography characterized by a quite rough and irregular texture with natural cavities (Fig. 10, a). The surface shows a spread and moderately reflective polish in relation to the topographic high points (Fig. 10, c). Edge roundings and levelled areas are also present. Considering the presence of edge roundings and polish even on the fractured edge, we can assume that the tool was used even after it was fractured (Fig. 10, b). Two extraction points were selected on this surface in relation to brown patches attached to polished areas.

The two profile surfaces are both characterized by an irregularly sinuous topography and the presence of both used and unused areas. Edge roundings and a moderately reflective polish are visible (Fig. 10, d). Three extraction points were selected in relation to brown patches attached to polished areas.

\subsection{Artefact 8 - HFT 1955/3 - HFT 192.20 (Layer VI)}

Artefact 8 is a disk shaped nummulitic limestone pebble used as a handstone and measuring $82 \times 66 \times 27 \mathrm{~mm}$ (Fig. 11). It is slightly convex on both the surfaces. One of the surface shows

three detachments. The artefact seems to have been only slightly used and it does not show any evident edge rounding, levelled areas, or linear striations (Figs. 11, a, c). Slightly reflective polish is only present in the central part of one of the two surfaces and affects only the topographic high points (Fig. 11, b). Three and two extraction points were selected respectively on each surface, in relation to brownish residues attached to the tool.

\section{Residues analysis}




\subsection{Extraction of the debris}

As already presented, different extraction points were selected for each artefact. Different tools showed compacted fine residues, not consistent with soil and firmly adhering to the worked surfaces. These deposits often appeared brownish in colour and highly reflective. These locations were selected for further micro sampling and analysis to determine their composition. Locations with major deposits of cave sediments were excluded from analysis, although they were visually assessed for the presence of any macro plant remains to determine what is present as background organic matter. Once we had identified locations of interest, these were 'spot sampled' following established protocols in Torrence and Barton (2006). From this, we obtained two types of samples referred to as dry and wet. All slides were examined at magnifications of 200x, 400x, 630x (oil imerision), using an Olympus and a Zeiss Axioscop compound microscope. Lighting conditions included brightfield and cross-polarized light.

\subsection{Dry samples}

All residues visibly adhering to the artefact surface, and which appeared of sufficiently quantity to be removed mechanically, were gently scraped free of the tool using either a sterile aluminium blade or a sterile fine acupuncture needle. The dry samples obtained in this way were placed onto a glass slide and a drop of ultrapure water was added in order to facilitate observations of the micro-fossils. A wet mount was preferred as this allows manipulation and rotation of objects and analysis of their 3D morphology. A coverslip was applied and kept in place by small drops of nail polish.

\subsection{Wet samples}

In areas of the tools where the residues were too small or difficult to be successfully dry sampled, such as small cracks, crevices and fissures, material was extracted by wet sampling. A small drop of ultrapure water was placed on the selected areas via a sterile disposable nylon pipette tip. The drop of water was allowed to rest for a few minutes and sometime a further drop 
was added when the water was absorbed by the residue or by the porosity of the tool. In some cases a fine sterile acupuncture needle was used to help detach residues from the surface. The water droplet was removed and mounted following the steps used in dry sampling.

\subsection{Identification and quantification of the residues}

The identification of all plant micro-remains relies on a good quality reference collection of modern plants. The reference collection used in this study consists of:

1) Species of plants already identified by previous macro-plant studies conducted by Morales and van der Veen (eg. Barker et al. 2008, 2009, 2010) (Table 1).

2) Plants and part of plants known to produce starch granules (e.g. Cyperaceae, Fabaceae, Poaceae) from Libya, but also from neighbouring areas of modern Egypt and southern Mediterranean regions. This was deemed necessary due to the complex vegetation history of Northern Africa, which comprises species of both Mediterranean and tropical origin during the Holocene (Barich, 2014; Giraudi et al., 2013; Sadori et al., 2011; Wasylikowa, 2001). Examples of starch granules from these species is provided in Fig. 12.

3) The identification of some starch granules and phytoliths was also supported by comparison with published data (eg. Henry et al., 2009; Leonard et al., 2015; Madella et al., 2013; Tao et al., 2015; Torrence and Barton, 2006; Wang et al., 2015; Yang et al., 2012, 2014).

Descriptive terminology of starch granules follows the International Code for Starch Nomenclature (ICSN 2011, $\quad$ http://www.fossilfarm.org/ICSN/Code.html). Descriptive terminology for phytoliths follows a combination between Piperno (2006) and Madella et al. (2005). Plant nomenclature of identified starch granules follows Cope and Hosni (1991). All recovered organic remains were counted; therefore data presented represents absolute counts.

\subsection{Soil, mineral grit and other contaminants}

None of the samples of stone tools were found to be free of inorganic debris and small lumps of soil. This is to be expected as the stone tools were dug from a secure archaeological deposits 
and a certain quantity of soil could be attached to the plants that were processed. All potential areas where large lumps of soil were adhering to the tools and/or potential contaminants were clearly visible were omitted from the analysis. For all the samples that were selected for analysis, we recorded the presence of inorganic debris and soil based upon their presence on the field of view, following procedures also used in soil micro-morphology, to which we remind for details (FitzPatrick, 1980). To avoid modern contamination, extraction and mounting were conducted in a clean environment where no modern material had been processed, dust monitored and blanks with mounting medias were conducted on a regular base.

\section{Results by category of remains}

The analysis yielded a variety of micro-debris of organic and inorganic origin, but in low concentration. Results are presented in Table 2.

\subsection{Starch granules}

Starch granules were retrieved during analysis in three main forms (Fig. 13), and are described in detail below:

1. Intact starch granules, whose identification was possible thanks to a still clearly visible morphology (Figs. 13, a1-3). These were retrieved only in Artefact 6, Extraction Point 6 (A6-E6).

2. Damaged starch granules (Fig. 13, b). The original morphology of these granules was lost, although some characteristics, such as hilum and birefringence are still visible. These were found in A5-E1 and A1-E1. These starches may have been damaged by grinding activity.

3. A third uncertain type consisted of masses of a birefringent substance, which is very similar to very small starch granules packed all together. These were found in A4-E4, but their origin could not be confirmed.

Starch granules belonging to types 2 and 3 are unlikely to provide further information because they cannot be clearly identified. 
Starch granules belonging to type 1, retrieved from tool A6-E6, are large, around and above 20 microns, sub-round to polyhedral in shape. They show a central fissured hilum and a high number of thin fissures radiating from it. Such fissures expand almost over the entire granule surface, giving the granules a distinctive stellate aspect and a very glossy appearance (Figs. 13, a1-3). Starch granules of such shape have been described in literature consistently as belonging to the tribe Paniceae and Andropogoneae (eg. Li et al., 2007; Madella et al. 2013; Wang et al., 2015; Yang et al. 2012). Examples from our modern reference material are provided in Fig. 12. Starch granules from species belonging to several tribes of the family Poaceae were in fact inspected and we could exclude upon size or morphology a number of potential candidates: starch granules of Triticeae, wheat tribe, which are lenticular and bimodal, and with an overall morphology which is very different from our specimens (Henry et al. 2009; Yang et al., 2012). Considering size and morphology, we could also exclude the tribes Avenae and Stipeae. Using our reference collection and published work, it was possible to exclude for size of the granules the sub-tribe Setariineae, and for the overall morphology of the granules the sub-tribe Panicineae, leaving the large granules retrieved most likely to belong to the sub-tribe Cenchrineae (Figs. 12, a and 13, a1-a4). In its overall, the starch granules found have an extraordinary resemblance to species belonging to the genus Cenchrus, which have starch granules sub-round to polyhedral, and the sub-round granules show a high number of fissures radiating from the hylum (Fig. 13, a4). It is also worth mentioning we noticed that both economic and non-economic species of the tribe Paniceae show some overlap in size and shape among the smaller granules (see Fig. 12) between genera and tribes as already pointed out by Wang et al. (2015). Caution therefore must be taken in the identification to species level, in areas of the world where a number of species of the same tribe grow, often in association.

\subsection{Phytoliths $\left(\mathrm{SiO}_{2} \cdot \mathrm{nH}_{2} \mathrm{O}\right)$}

Phytoliths were retrieved from almost all the tools. Most of them appeared broken, possibly due to the grinding action carried out on the plant material from which they have originated, but it is equally possible that they were damaged by transport in soil or wind. Little can be said about those types, as they have been badly damaged. However, considering some intact specimens, we could determine the presence of two types. 
The first type was more common and consisted of long smooth/sinuate phytoliths, between 20 and 25 microns in length, with a smooth to sinuate surface (an example is provided in Fig. 13, c1). These types of phytolith are found in many monocotyledon and some dicotyledon plant species (Albert et al., 2007). However they are very common in the order of Pooideae of the family Poaceae (Piperno, 2006), which are also very common in Libya (Sherif and Siddiqi, 1988).

Only two phytoliths belonging to the second type were retrieved, and they were broken. They are short cell simple bilobate (Fig. 13, c2). They are typical of the sub-family Panicoideae, but they are also found in species belonging to other sub-families of the family Poaceae (Barboni and Bremond, 2009; Piperno, 2006). Due to the low diagnostic nature of the recovered phytoliths it is difficult to assess their origin, however the presence of starch granules of the tribe Paniceae, suggests that such remains may have entered the archaeological record as consequence of the food processing of these plants.

\subsection{Wood, plant fibers, micro-charcoal and other plant tissues}

A number of samples yielded a variety of non-diagnostic plant fibers and plant tissue (Fig. 13, d), including wood, and micro-charcoal: A1 (E1, E2 and E3), A4 (E4), A5 (E1), A6 (E1, E2, E4 and E6), A7 (E1). The presence of soft and hard plant tissue suggests that a variety of plant debris was possibly processed with the tools. This could be explained in different ways:

1. The use of wooden tools in plant processing is documented in modern groups, such as Tuaregh. Wooden tools, such as spatulas, could have been used to scratch the tool's surface in order to collect the ground residue from the tool's surface. Such practice was directly observed by one of the authors (AR) during fieldwork in southern Libya.

2. The stone tool has been used to sharp wooden part/objects (this need to go with the tool morphology).

3. Stone tools could have been used to soften up and/or separate plant fiber for specific tasks, such as cordage. 
All of the above activities could easily produce the debris observed on the tools. Equally, some of the plant material could be the result of grinding of plant for food as testified by the presence of starch granules.

\subsection{Fungi}

Fungal spores fragments were found in two stone tools: in one single spore in tool A1-E5, and in cluster of one single-celled fungal spore and hyphal fragment in tool A7-E1 (Figs. 13, e1e3). These were similar to those found in phylum Ascomycota, which contains several species common in soil and parasite of plants ( $\mathrm{Li}$ et al. 2007). Pathways of inclusion of such debris are many, as the spores are very often airborne at least for a period of time. However, as already mentioned above, the combination of high amount of spores and hyphal fragments and starch granules could suggest that more starch granules were present and the fungal hyphae and spores had 'fed on' them.

\subsection{Inorganic debris and soil}

Few samples yielded a very low amount of soil and mineral grit which occupied around 2\% of the field of view (see table 1); in the remaining samples, mineral grit and soil fleck occupied between $5 \%$ to $40 \%$ of the field of view. It is worth noting that the extraction points that yielded higher amounts of plant remains showed a very low amount of soil residue and grit. In particular the extraction points which yielded starch granules were found to have $2 \%$ or less of mineral grit. On the contrary, the residue that resulted to be rich in soil and grit did not yield any plant remains apart from phytoliths, which were long cell phytoliths.

The presence of starch granules due to modern contamination can also be excluded since starch granules belonging to the tribe Paniceae and, among those, in particular species of genus Cenchrus, do not grow in England, where the artefacts are stored and they are rarer than other grasses in the northern part of Libya today (Sherif and Siddiqi, 1988). When the organic residue data is combined with the results of the use wear analysis we feel that the archaeological integrity of the organic residues recovered from these tools by use of spot samples is high.

\section{Discussion}


One of the remarkable aspects of the study carried out on the non-knapped stones assemblage from the Neolithic layer of the Haua Fteah cave is the low amount of tools that were found to be associated to the use of plant material. The absence of lower grinding elements, the low number of handstones/upper elements and, among these, the highly opportunistic manufacturing strategy, with the almost exclusive use of naturally shaped pebbles that were collected in the vicinity of the cave (only one upper grinder was found to have been ground from a beach sandstone boulder) point to a low presence of plant processing activity inside the cave or, at lest, to a type of processing which only marginally involved the use of stone tools. This picture was confirmed by the functional analysis on the artefacts, which yielded only a low amount of starch granules and other plant micro-remains, even if this could be at least in part due to preservation issues, including fungal activity present in the ground.

Considering the plant micro-remains that could be identified, it is worth noting that such remains do not belong to any of the species present in the Haua Fteah plant macro-remains assemblage (Barker et al., 2008, 2009, 2010). Among the wild species belonging to the sub-tribe Cenchrineae that still grow in Northern Libya today, Cenchrus ciliaris and Pennisetum elatum (Fig. 12, c) are mentioned in Flora of Libya, while Cenchrus biflorus (Fig. 13, a4) is known to grow in the Sahara and Sahelian regions (Corti, 1942; Ozenda, 1958). All the species belonging to the sub-tribe Cenchrineae show a ring of "bristles" of variable thickness, depending on the species, that need to be removed before consumption. It is possible that processing of such plant material affected its survival in the archaeobotanical record, especially by charring processes, the main form of preservation at the cave. From an archaeobotanical point of view, studies about preservation and survival of cereal grains to the charring process have shown that millets do not survive as well as wheat and barley grains to such process, possibly due to the small size of their grains or different properties of the chemistry of the starch granules (Märkle and Rösch, 2008; Yang et al., 2011). The recovery is also difficult, again because of the small size of such grains, a fact already pointed out by Madella et al. (2013). This could explain the absence of species of the sub-tribe Cenchrineae from the macrobotanical record.

Wild species belonging to the tribe Paniceae, sub-tribe Cenchrineae, are still collected as food in a number of African regions, in particular at times of other food shortage. In particular, Cenchrus biflorus, close relative of Cenchrus ciliaris, which is still present in Northern Libya, is still widely exploited by several African groups such as Tuaregh and Zaghawa. It is an annual 
grass, regularly collected as famine food across the Sahara and the Sahel, and is known as one of the 'lost crops of Africa' (Harlan, 1989a, 1989b; National Research Council, 1996). The importance of species of Cenchrus lies mainly in its exceptional nutritional qualities and its time of ripeness, at the end of the year, makes the plant available when other wild grasses have completed seeding (Tubiana, Tubiana, 1977: 16).

Being a low cost and easily reversible strategy, which does not involve a great productive capacity by the human group, exploitation of wild plants is one of the most adopted strategies during famine periods (Watts, 1983; 1988). This is due especially to the characterstics of a number of these plants, which can easily resist to harsh environments and periods of strong climatic stress. During shortage periods, some of these plants could thus be selected for their nutritive values, even if they were costly to use, especially in terms of processing time and energies. This is, for example, the case of species of Cenchrus, whose gathering and processing are particularly time and energy consuming. When food scarcity is recurrent, wild foods often become a primary element of the diet even during times of better environmental conditions and normal food supply (Huss-Ashmore and Johnston, 1994: 63). It is thus not surprising that, even after the introduction of domestic caprines in Cyrenaica at the beginning of the $8^{\text {th }}$ millennium $\mathrm{BP}$, these species represented an addition to and not a replacement of wild resources.

The macrobotanical assemblage coming from the new excavated sample column in the Haua Fteah cave did not show the presence of domesticated crops in the Neolithic contexts of the cave. Considering this and the absence, on grinding stones, of micro-fossils that can be ascribed to domestic species, we can assume that the exploitation of domestic wheat and barley in the cave during the Mid Holocene, although it cannot be completely ruled out, it remained only a very marginal activity in the economy of the groups who inhabited the region. Also the pollen analysis showed only sparse cereal pollen grains at Haua Fteah (Hunt et al., 2011: 23).

The absence of proper farming activities in the Haua Fteah area seems also to be confirmed by the absence of other types of tools usually connected with the exploitation of plants, such as sickle blades. Insofar as harvesting tools are concerned, the Haua Fteah lithic complex did not yield any specimens except for two small gloss-banded blades, which were interpreted as probable sickle elements (McBurney, 1967: 298). The great number of sickle elements on blades with bifacial retouch and serrated working edges, typical of the Fayum area, or other types of sickle blades are not present at Haua Fteah. As also shown in other contexts of the Egyptian 
Western Desert, it is likely that the gathering of wild plant could also have been carried out using bare hands or opportunistic debitage elements that were used for short time before being discarded (Lucarini, 2014).

Indirect evidence of possible farming activities in Cyrenaica came only from the Chersa coastal plain, located c. $35 \mathrm{~km}$ east of Haua Fteah. Here, stratified Helix sp. land snails were dated to 5741-5617 and 5578-5576 cal. BP. Considering their short lifespan, they give age estimates almost contemporary with the processes that buried them. These dates suggest that during Mid Holocene a lot of sediment was mobilized in the area by intense human presence and activities, since there is no indication of a major climatic event at this time in the region (Antoniadou, 2012; pers. comm. 2015).

Moving away from a simplistic focus on the beginning of 'agriculture' and from the traditional dichotomy wild Epipalaeolithic Vs. domestic Neolithic, the data so far available for the Jebel Akhdar, but also for the western Lybian coastal range, the Jebel Gharbi (Barich 2014; Lucarini 2013), yielded evidence of a far more complex and articulated pattern of exploitation and interaction with the environment. Our results from the Haua Fteah cave confirmed that North Libyan Mid Holocene groups developed a very successful and low risk economy based on foraging and hunting a broad-spectrum of wild resources, mainly shellfish and plant, integrated with domestic small livestock keeping. This was preferred to only relying on domestic crops and animals, which is a highly risky strategy especially in regions characterized by strong climatic and rain variations.

\section{Conclusions}

The non-knapped stone assemblage retrieved from the Neolithic layers of Haua Fteah mainly consists of unmodified pebbles and other stones that do not show sign of manufacturing and that were collected in the vicinity of the cave. Only two ground handstones were found. Of the 79 analyzed implements, we carried out usewear and residue analysis on eight handstones, six of which showed morphological features consistent with their use as grinding tools. The opportunistic character of the assemblage was also confirmed by the frequent traces of a secondary use, especially for knapping activities, detected on several tools. The results of the residue analysis confirmed the tools were mainly used to process plants and wood. Starches were 
retrieved as intact starch granules, damaged starch granules, and starchy masses of a birefringent substance. Only one tool yielded intact starch granules that could be identified as belonging to the tribe Paniceae and very likely to the sub-tribe Cenchrineae. These plants were not retrieved from previous archaeobotanical work on plant macro-remains. Although the number of starch granules yielded from the analysis may appear low in number, the presence of starch granules that do not belong to any of the domesticated crops and to species identified in the plant macroremains is therefore a notable contribution to the existing data from the Haua Fteah cave.

The gathering of wild grasses is well documented in the archaeological record and is also widely accepted as a common practice in ancient Africa for both the Sahara and the sub-Saharan regions during the Mid Holocene. However, less is known about uses of wild grasses in the northern and coastal areas of the African continent. This is mainly due to the lack of proper research techniques especially for the old excavated sites and to a major enphasis given to certain species, such as the domesticated ones. Our paper has shown how the combined application of usewear and residue analysis to stone tools with high potential and integrity, which has been only rarely applied to North African assemblages, may help to retrieve information on plant uses not otherwise available.

\section{Acknowledgements}

This research was conducted as a part of the Marie Skłodowska-Curie Project FP7-People2012-IEF 'AGRINA', funded by the European Commission. We gratefully acknowledge the permission and support of the Department of Antiquities of Libya to undertake the Cyrenaican Prehistory Project and the financial support from the European Research Council and the Society for Libyan Studies. We are also grateful to the Presidents of the Department of Antiquities Giuma Anag, Saleh Rageb Aghab and to Mustafa Turjman, currently Head of Archaeological Researches of the Department of Antiquities, for the help and support given to the Project. Usewear analysis was carried out at the George Pitt-Rivers Laboratory for bio-archaeology, McDonald Institute for Archaeological Research, University of Cambridge. Residue analysis was carried out at the BioArCh Laboratories, University of York. We are extremely grateful to Anita Antoniadou, Lucy Farr, Sacha Jones, Jacob Morales, Christina Tsoraki, and the two anonymous reviewers for their helpful comments and suggestions. 


\section{References}

Adams, J., Delgado, S., Dubreuil, L., Hamon, C., Plisson, H., Risch, R., 2009. Functional analysis of macro-lithic artefacts: a focus on working surfaces. In: Sternke, F., Eigeland, L., Costa, L.-J. (Eds.), Non-Flint Raw Material Use in Prehistory. Old prejudices and new directions. Proceedings of the XV UISPP World Congress (Lisbon, 4-9 September 2006), pp. 43-66.

Albert, R.M., Bar-Yosef, O., Weiner, S., 2007. The use of plant material in Kebara cave: phytoliths and mineralogical analyses. In: Bar-Yosef, O., Meignen, L. (Eds.), Kebara Cave, Mt. Carmel, Israel: The Middle and Upper Paleolithic Archaeology, Part I. Peabody Museum of Archaeology and Ethnology, Harvard University, Cambridge, MA, pp. 147-162.

Antoniadou, A., 2012. The Geoarchaeology of Cyrenaica, Libya. Ph.D. thesis. Queen's University, Belfast.

Barakat, H.N., Fahmy, A.G., 1999. Wild grasses as "Neolithic" food resources in the eastern Sahara - a review of the evidence from Egypt. In: van der Veen, M. (Ed.), The Exploitation of Plant Resources in Ancient Africa. Kluwer Academic / Plenum Publishers, New York, pp. 33-46.

Barboni, D., Bremond, L., 2009. Phytoliths of East African grasses: an assessment of their environmental and taxonomic significance based on floristic data. Review of Palaeobotany and Palynology 158 (1), 29-41.

Barich, B.E., 2014. Northwest Libya from the Early to Late Holocene: new data on environment and subsistence from the Jebel Gharbi. Quaternary International 320, 15-27.

Barker, G., 2009. The Agricultural Revolution in Prehistory. Why did Foragers become Farmers? Oxford University Press, Oxford.

Barker, G., Antoniadou, A., Armitage, S., Brooks, I., Candy, I., Connell, K., Douka, K., Drake, N., Farr, L., Hill, E., Hunt, C., Inglis, R., Jones, S., Lane, C., Lucarini, G., Meneely, J., Morales, J., Mutri, G., Prendergast, A., Rabett, R., Reade, H., Reynolds, T., Russell, N., Simpson, D., Smith, B., Stimpson, C., Twati, M., White, K., 2010. The Cyrenaican Prehistory Project 2010: the fourth season of investigations of the Haua Fteah cave and its landscape, and further results from the 2007-2009 fieldwork. Libyan Studies 41, 63-88. 
Barker, G., Antoniadou, A., Barton, H., Brooks, I., Candy, I., Drake, N., Farr, L., Hunt, C., Abdulsaid Abdulhamid, I., Inglis, R., Jones, S., Morales, J., Morley, I., Mutri, G., Rabett, R., Reynolds, T., Simpson, D., Twati, M., White, K., 2009. The Cyrenaican Prehistory Project 2009: the third season of investigations of the Haua Fteah cave and its landscape, and further results from the 2007-2008 fieldwork. Libyan Studies 40, 55-94.

Barker, G., Basell, L., Brooks, I., Burn, L., Cartwright, C., Cole, F., Davison, J., Farr, L., Grün, R., Hamilton, R., Hunt, C., Inglis, R., Jacobs, Z., Leitch, V., Morales, J., Morley, I., Morley, M., Pawley, S., Pryor, A., Rabett, R., Reynolds, T., El-Rishi, H., Roberts, R., Simpson, D., Stimpson, C., Touati, M., van der Veen, M., 2008. The Cyrenaican Prehistory Project 2008: the second season of investigations of the Haua Fteah cave and its landscape, and further results from the initial (2007) fieldwork. Libyan Studies 39, 175-221.

Barker, G., Bennett, P., Farr, L., Hill, E., Hunt, C., Lucarini, G., Morales, J., Mutri, G., Prendergast, A., Pryor, A., Rabett, R., Reynolds, T., Spry-Marques, P., Twati, M., 2012. The Cyrenaican Prehistory Project 2012: the Fifth Season of Investigations of the Haua Fteah Cave. Libyan Studies 43, 115-136.

Barker, G., Hunt, C., Reynolds, T., Brooks, I., el-Rishi, H., 2007. The Haua Fteah, Cyrenaica (NorthEast Libya): renewed investigations of the cave and its landscape, 2007. Libyan Studies 38, 2-22.

Barton, H., 2007. Starch residues on museum artefacts: implications for determining tool use. Journal of Archaeological Science 34 (10), 1752-1762.

Bellwood, P., 2005. First Farmers. The Origins of Agricultural Societies. Wiley-Blackwell Publishing, Malden, MA.

Brochier, J., Thinon, M., 2003. Calcite crystals, starch grains aggregates or... POCC? Comment on 'calcite crystals inside archaeological plant tissues'. Journal of Archaeological Science 30 (9), 1211-1214.

Chaves, S.A.M., Reinhard, K.J., 2003. Paleopharmacology and pollen: theory, method, and application. Memórias do Instituto Oswaldo Cruz, Rio de Janeiro, 98 (Suppl.1), pp. 207211.

Cope, T.A., Hosni, H.A., 1991. A key to Egyptian grasses. Royal Botanic Gardens, Kew.

Corti, R., 1942. Flora e vegetazione del Fezzan e della regione di Gat. Reale Società Geografica Italiana, Firenze. 
de Faucamberge, E., 2015. Le site néolithique d'Abou Tamsa (Cyrénaïque, Libye). Apport à la préhistoire du nord-est de l'Afrique. Collection Études Libyennes 2. Riveneuve éditions, Paris.

di Lernia, S., 2013. The emergence and spread of herding in North Africa. A critical Reappraisal. In: Mitchell, P., Lane, P. (Eds.), The Oxford Handbook of African Archaeology. Oxford University Press, Oxford, pp. 527-540.

Douka, K., Jacobs z., Lane, c., Grün, R., Farr, L., Hunt, c., Inglis, R.H., Reynolds, T., Albert, P., Aubert, M., Cullen, v., Hill, e., Kinsley, L., Roberts, R.G., Tomlinson, E.L., Wulf, S., Barker, G. The chronostratigraphy of the Haua Fteah cave (Cyrenaica, northeast Libya). Journal of Human Evolution 66, 39-63.

Dubreuil, L., 2002. Etude fonctionelle des outils de broyage natoufiens: nouvelles perspectives sur l'émergence de l'agriculture au Proche-Orient. Ph.D. Thesis. Université Bordeaux 1, Bordeaux.

Fahmy, A.G., 2001. Palaeoethnobotanical Studies of the Neolithic Settlement in Hidden Valley, Farafra Oasis, Egypt. Vegetation History and Archaeobotany 10, 235-246.

Fahmy, A.G., 2014. Plant food resources at Hidden Valley. In: Barich, B.E., Lucarini, G., Hamdan, M.A., Hassan, F.A. (Eds.), From Lake to Sand. The Archaeology of Farafra Oasis, Western Desert, Egypt. All'Insegna del Giglio, Florence, pp. 333-344.

FitzPatrick, E.A., 1980. Soils: their formation, classification and distribution. Longman, New York, NY.

Gautier, A., 1980. Contribution to the archaeozoology of Egypt. In: Wendorf, F., Schild, R. (Eds.), Prehistory of the Eastern Sahara. Academic Press, New York, pp. 317-344.

Gautier, A., 1984. Archaeozooogy of the Bir Kiseiba region, Eastern Sahara. In: Wendorf, F., Schild, R. (Eds.), Cattle-keepers of the Eastern Sahara : the Neolithic of Bir Kiseiba. South Methodist University, Dallas, pp. 317-344.

Gautier, A., 2001. The early to late Neolithic archefaunas from Nabta and Bir Kiseiba. In: Wendorf, F., Schild, R. (Eds.), Holocene Settlement of the Egyptian Sahara, Volume 1, The Archaeology of Nabta Playa. Kluwer Academic/Plenum Publishers, New York, pp. 609635.

Gautier, A., 2014. Animal remains from the Hidden Valley Neolithic site, Farafra Oasis. In: Barich, B.E., Lucarini, G., Hamdan, M.A., Hassan, F.A. (Eds.), From Lake to Sand. The 
Archaeology of Farafra Oasis, Western Desert, Egypt. All'Insegna del giglio, Firenze, pp. 369-376.

Giraudi, C., Mercuri, A.M., Esu, D., 2013. Holocene palaeoclimate in the northern Sahara margin (Jefara Plain, northwestern Libya). The Holocene 23 (3), 339-352.

Haas, J.N., 2010. Fresh insights into the palaeoecological and palaeoclimatological value of Quaternary non-pollen palynomorphs. Journal of Archaeological Science 19 (5-6), 389.

Hamon, C., 2008. Functional analysis of stone grinding and polishing tools from the earliest Neolithic of north-western Europe. Journal of Archaeological Science 35, 1502-1520.

Harlan, J.R., 1989a. Wild grass seeds as food sources in the Sahara and Sub-Sahara. Sahara 2, 69-74.

Harlan, J.R., 1989b. Wild-grass seed harvesting in the Sahara and Sub-Sahara of Africa. In

Harris, D.R., Hillman, G.C. (Eds.), Foraging and Farming. The evolution of plant exploitation. One World Archaeology. Unwyn Hyman, London, pp. 79-98.

Hart, T.C., 2011. Evaluating the usefulness of phytoliths and starch grains found on survey artifacts. Journal of Archaeological Science 38 (12), 3244-3253.

Henry, A. G., Hudson, H. F., Piperno, D. R., 2009. Changes in starch grain morphologies from cooking. Journal of Archaeological Science, 36 (3), 915-922.

Hill, E., Hunt, C.O., Lucarini, G., Mutri, G., Farr, L., Barker, G. 2015. Land gastropod piercing during the Late Pleistocene and Early Holocene in the Haua Fteah, Libya. Journal of Archaeological Science: Reports 4, 320-325.

Hunt, C.O., Reynolds, T.G., El-Rishi, H.A., Buzaian, A., Hill, E., Barker, G.W., 2011. Resource pressure and environmental change on the North African littoral: Epipalaeolithic to Roman gastropods from Cyrenaica, Libya. Quaternary International 244, 15-26.

Hunt, H.V., Vander Linden, M., Liu, X., Motuzaite-Matuzeviciute, G., Colledge, S., Jones, M.K., 2008. Millets across Eurasia: chronology and context of early records of the genera Panicum and Setaria from archaeological sites in the Old World. Vegetation history and archaeobotany 17 (1), 5-18.

Huss-Ashmore, R., Johnston, S.L. 1994. Wild Plants as Cultural Adaptations to Food Stress. In: Etkin, N.L. (Ed.), Eating on the Wild Side. The Pharmacologic, Ecologic and Social Implications of Using Noncultigens. The University of Arizona Press, Tucson, pp. 62-82. 
Jórdeczka, M., Królik, H., Masojć, M., Schild, R., 2013. Hunter-Gatherer Cattle-Keepers of Early Neolithic El Adam Type from Nabta Playa: Latest Discoveries from Site E-06-1. African Archaeological Review 30, 253-284.

Krzyżaniak, L., Kobusiewicz, M. (Eds.), 1984. Origin and Early Development of FoodProducing Cultures in North-Eastern Africa. Polish Academy of Science, Poznan Branch Poznan Archaeological Museum, Poznan.

Leonard, C., Vashro, L., O'Connell, J.F., Henry, A.G., 2015. Plant microremains in dental calculus as a record of plant consumption: A test with Twe forager-horticulturalists. Journal of Archaeological Science: Reports 2, 449-457.

Li, D., Yang, C.S., Harrington, F., 2007. Microscopic analytical methods for fungi. In: Yang, C.S., Heinsohn, P. (Eds.), Sampling and analysis of indoor microorganism. John Wiley \& Sons, Hoboken, NJ, pp. 75-103.

Limaye, R.B., Kumaran, K.P.N., Nair, K.M., Padmalal, D., 2007. Non-pollen palynomorphs as potential palaeoenvironmental indicators in the Late Quaternary sediments of the west coast of India. Current Science 92 (10), 1370-1382.

Linseele, V., Marinova, E., Van Neer, W., Vermeersch, P.M., 2010. Sites with Holocene Dung Deposits in the Eastern Desert of Egypt: Visited by Herders? Journal of Arid Environments $74,818-828$.

Lucarini, G. 2014. Exploitation and management of wild grasses at Hidden Valley, Farafra Oasis. In: Barich, B.E., Lucarini, G., Hamdan, M.A., Hassan, F.A. (Eds.), From Lake to Sand. The Archaeology of Farafra Oasis, Western Desert, Egypt. All'Insegna del Giglio, Florence, pp. 345-367.

Madella, M., Alexandre, A., Ball, T.B., 2005. International Code for phytolith nomenclature 1.0. Annals of Botany 96 (2), 253-260.

Madella, M., García-Granero, J.J., Out, W.A., Ryan, P., Usai, D., 2014. Microbotanical Evidence of Domestic Cereals in Africa 7000 Years Ago. PLoS ONE 9 (10), e110177.

Madella, M., Lancellotti, C., García-Granero, J.J., 2013. Millet microremains - an alternative approach to understand cultivation and use of critical crops in Prehistory. Archaeological and Anthropological Sciences. DOI 10.1007/s12520-013-0130-y.

Märkle T., Rösch, M., 2008. Experiments on the effects of carbonization on some cultivated plant seeds. Vegetation History and Archaeobotany, 17 (1), 257-263. 
McBurney, C.B.M., 1967. The Haua Fteah (Cyrenaica) and the Stone Age of the South-East Mediterranean. Cambridge University Press, Cambridge.

Mercuri, A.M., 2001. Preliminary analyses of fruits, seeds and few plant macrofossils from the Early Holocene sequence. In: Garcea, E.A.A. (Ed.), Uan Tabu in the settlement history of the Libyan Sahara. Arid Zone Archaeology, Monographs 2. All'Insegna del Giglio, Florence, pp. 189-210.

Morales, J., Pérez-Jordà, G., Peña-Chocarro, L., Zapata, L., Ruíz-Alonsoa, M., López-Sáeza, J.A., Linstädter, J., 2013. The origins of agriculture in North-West Africa: macro-botanical remains from Epipalaeolithic and Early Neolithic levels of Ifri Oudadane (Morocco). Journal of Archaeological Science 40 (6), 2659-2669.

Motuzaite-Matuzeviciute, G., Hunt, H.V., Jones, M.K., 2012. Experimental approaches to understanding variation in grain size in Panicum miliaceum (broomcorn millet) and its relevance for interpreting archaeobotanical assemblages. Vegetation history and archaeobotany 21 (1), 69-77.

National Research Council, 1996. Lost Crops of Africa. Volume I: Grains. National Academy Press, Washington, D.C.

Ozenda, P., 1958. Flore du Sahara Septentrional et Central. CNRS, Paris.

Perry, L., 2002. Starch analyses reveal multiple functions of quartz "manioc" grater flakes from the orinoco basin, Venezuela. Interciencia 27 (11), 635-639.

Perry, L., 2004. Starch analyses reveal the relationship between tool type and function: an example from the Orinoco valley of Venezuela. Journal of Archaeological Science 31 (8), 1069-1081.

Piperno, D.R., 2006. Phytoliths. A comparative Guide for Archaeologists and Paleoecologists. Altamira Press, Lanham, MD, New York, NY, Toronto, Oxford.

Piperno, D.R., Weiss, E., Holst, I., Nadel, D., 2004. Processing of wild cereal grains in the Upper Palaeolithic revealed by starch grain analysis. Nature 430 (7000), 670-673.

Reimer, P.J., Bard, E., Bayliss, A., Beck, J.W., Blackwell, P.G., Bronk Ramsey, C., Buck, C.E., Cheng, H., Edwards, R.L., Friedrich, M., Grootes, P.M., Guilderson, T.P., Haflidason, H., Hajdas, I., Hatté, C., Heaton, T.J., Hogg, A.G., Hughen, K.A., Kaiser, K.F., Kromer, B., Manning, S.W., Niu, M., Reimer, R.W., Richards, D.A., Scott, E.M., Southon, J.R., Turney, 
C.S.M., van der Plicht, J., 2013. IntCal13 and MARINE13 radiocarbon age calibration curves 0-50000 years calBP. Radiocarbon 55 (4), 1869-1877.

Sadori, L., Jahns, S., Peyron, O., 2011. Mid-Holocene vegetation history of the central Mediterranean. The Holocene 21 (1), 117-129.

Sherif, A.S., Siddiqi, M.A., 1988. Flora of Libya: 145. Poaceae. National Herbarium, Al Faateh University, Tripoli.

Shirai N. 2010., The Archaeology of the First Farmer-Herders in Egypt: New insights into the Fayum Epipalaeolithic and Neolithic. Leiden University Press, Leiden.

Smith, A.B., 2005. African Herders: Emergence of Pastoral Tradition. AltaMira Press, Walnut Creek, CA.

Tao, D., Zhang, J., Zheng, W., Cao, Y., Sun, K., Jin, S.A., 2015. Starch grain analysis of human dental calculus to investigate Neolithic consumption of plants in the middle Yellow River Valley, China: A case study on Gouwan site. Journal of Archaeological Science: Reports 2, 485-491.

Thanheiser, U. 2011. Island of the Blessed: 8000 Years of Plant Exploitation in the Dakhleh Oasis, Egypt. In: Fahmy, A.G., Kahlheber, S., D’Andrea, A.C. (Eds.), Windows on the African Past: Current Approaches to African Archaeobotany. Africa Magna Verlag, Frankfurt, pp. 79-90.

Torrence, R., Barton, H. (Eds.), 2006. Ancient starch research. Left Coast Press, Inc., Walnut Creek, CA.

Tubiana, M.J., Tubiana, J., 1977. The Zaghawa from an Ecological Perspective. A.A. Balkema, Rotterdam.

Vaughan, J.G., Geissler, C., 2000. The New Oxford Book of Plants. Oxford University Press, Oxford.

Vermeersch, P.M., Linseele, V., Marinova, E., Van Neer, W., Moeyersons, J., Rethemeyer, J. 2015. Early and Middle Holocene Human Occupation of the Egyptian Eastern Desert: Sodmein Cave. African Archaeological Review 32, 465-503.

Vermeersch, P.M., Van Peer, P., Moeyersons, J., Van Neer, W., 1994. Sodmein Cave Site, Red Mountains (Egypt). Sahara 6, 32-40.

Wang, X., Jiang, H., Shang, X., Wang, T., Wu, Y., Zhang, P., Wang, W., Wang, C., 2014. Comparison of dry ashing and wet oxidation methods for recovering articulated husk 
phytoliths of foxtail millet and common millet from archaeological soil. Journal of Archaeological Science 45, 234-239.

Wang, T.T., Fuller, B.T., Wei, D., Chang, X.E., Hu, Y.W., 2015. Investigating Dietary Patterns with Stable Isotope Ratios of Collagen and Starch Grain Analysis of Dental Calculus at the Iron Age Cemetery Site of Heigouliang, Xinjiang, China. International Journal of Osteoarchaeology. DOI: 10.1002/oa.2467.

Wasylikowa, K., 2001. Site E-75-6: Vegetation and Subsistence of the Early Neolithic at Nabta Playa, Egypt, Reconstructed from Charred Plant Remains. In: Wendorf, F., Schild R., Associates (Eds.), Holocene Settlement of the Egyptian Sahara. The Archaeology of Nabta Playa. Volume 1. Kluwer Academic / Plenum Publishers, New York, NY, pp. 544-591.

Wasylikowa, K., Schild, R., Wendorf, F., Krolik, K., Kubiak-Martens, L., Harlan, J.R., 1995. Archaeobotany of the early Neolithic site E-75-6 at Nabta Playa, Western Desert, south Egypt. Acta Palaeobotanica 35 (1), 33-155.

Watling, R., Seaward, M., 1976. Some observations on puff-balls from British archaeological sites. Journal of Archaeological Science 3 (2), 165-172.

Watts, M. 1983. Silent violence. University of California Press, Berkeley.

Watts, M. 1988. Coping with the market: Uncertainty and food securing among Hausa peasants. In: de Garine, I., Harrison, G.A. (Eds.), Coping with uncertainty in food supply. Clarendon Press, Oxford, pp. 260-289.

Wendrich, W., Taylor, R.E., Southon, J. 2010. Dating stratified sites at Kom K and Kom W: Fifth millennium BCE radiocarbon ages for Fayum Neolithic. Nuclear Instruments and Methods in Physics Research B 268 (7-8), 999-1002.

Yang, C.S., Heinsohn, P., 2007. Sampling and Analysis of Indoor Microorganism. John Wiley \& Sons, Hoboken, NJ.

Yang, X., Ma, Z., Li, Q., Perry, L., Huan, X., Wan, Z., Li. M., Zheng, J., 2014. Experiments with lithic tools: understanding starch residues from crop harvesting. Archaeometry 56 (5), 828840.

Yang, X., Zhang, J., Perry, L., Ma, Z., Wan, Z., Li, M., Diao, X., Lu, H., 2012. From the modern to the archaeological: starch grains from millets and their wild relatives in China. Journal of Archaeological Science 39 (2), 247-254. 


\section{Captions to figures and tables}

Fig. 1: Map of Cyrenaica and Jebel Akhdar with the archaeological sites mentioned in the text.

Fig. 2: Haua Fteah. Schematic drawing of the excavated trenches.

Fig. 3: Calibration of the AMS determinations from Haua Fteah Neolithic contexts using OxCal 4.2.4 (Bronk Ramsey 2013); r:5; IntCal 13 atmospheric curve (Reimer et al. 2013). OxA: determinations from CPP excavation; NPL and W: determinations from McBurney excavation.

Fig. 4: Artefact 1 - HFT 1955/7 - HFT 399.00-55 - Ground turtleshell-type handstone a: short striations; b: levelled areas and slightly reflective polish; c: brown residues; d: white crust-like areas; e: highly reflective polish.

Fig. 5: Artefact 2 - HFT 1955/7 - HFT 399.00-55 - Disk shaped pebble a-b: pecked areas; c: battered area.

Fig. 6: Artefact 3 - HFT 1955/7 - HFT 399.00-55 - Egg shaped pebble a: striations; b: fractures.

Fig. 7: Artefact 4 - HFT 1955/3 (1) - HFT 192.09 - Fragmentary disk shaped pebble a: shallow circular depression; b-c: moderately reflective polish; d: pits and superficial fractures.

Fig. 8: Artefact 5 - HFT 1955/5 - HFT 193.14.2005 - Fragmentary disk shaped pebble a, d: levelled and fractured areas; b: dark brown residue; c: irregularly flat topography; d: pits and fractures.

Fig. 9: Artefact 6 - HFT 1955/9 - HFT 160.02.2005 - Turtleshell shaped pebble a: levelled areas; b, f: highly reflective polish; c: striated brown patch; d: fibrous plant residues; e: fractures.

Fig. 10: Artefact 7 - HFT 1955/3 - HFT 192.20 - Fragmentary pebble a: irregular sinuous topography; $b$, d: edge roundings and polish; c: moderately reflective polish.

Fig. 11: Artefact 8 - HFT 1955/3 - HFT 192.20 - Disk shaped pebble a, c: unused surface; b: slightly reflective polish.

Fig. 12: Example of modern reference collection of starch granules belonging to the tribes Andropogoneae and Paniceae. Scale: $20 \mu \mathrm{m}$. 
a: Sorghum bicolor (Andropogoneae, Libya); b: Brachiaria sp. (Setariineae); c: Pennisetum elatum (Cenchrineae, Libya); d: Echinochloa colona (Panicinineae, Egypt); e: Setaria verticillata (Setariineae, Southern Italy).

Fig. 13: Plant micro-remains from the archaeological tools. Scale: $20 \mu \mathrm{m}$.

a1-a3: intact starch granules of sub-tribe Cenchrineae; a4: modern starch granules of Cenchrus biflorus (Fezzan, Libya). b: damaged starch granules. c1: long smooth/sinuate phytolith; c2: bilobate phytolith; d: plant tissue; e1: Hypha fragment; e2-e3: fungal spores.

Table 1: Species of plant macro-remains retrieved from the Upper Trench's re-excavated contexts of Haua Fteah (after Morales and van der Veen, in Barker et al. 2008, 2009, 2010).

Table 2: Summary table of the plant micro-remains retrieved from the Haua Fteah non-knapped stone tools

Key: ext: extraction point; $p l f b$ : plant fibers; $l$ sm cl phy: long smooth cell phytoliths; blb phy: bilobate phytolith; srt cl phy: short cell phytolith; st un: undiagostic starch granule; st Pan: Paniceae starch granule; st dmg: damaged starch granule; $f g s p$ : fungal spore; $f g$ hyp: fungal Hypha; $p l$ ts: plant tissue and cells; pl: pollen granule; soil phy: soil with phytoliths; $m c h$ : microcharcoal. 